\title{
Legacies of Love, Peace and Hope: How Bioethics Education can Overcome Hatred and Divide
}

\author{
Darryl R.J. Macer
}

Ph.D., Hon. D., MPH, President, American University of Sovereign Nations (AUSN), USA; Director, Eubios Ethics Institute, New Zealand, Japan and Thailand; Secreary, Asian Bioethics Association

Email: darryl@eubios.info Web: www.eubios.info

DOI: https://doi.org/10.3329/bioethics.v11i3.51220

\begin{abstract}
In our pursuit of a good life (eubios), both individuals and societies, need to educate themselves on the pursuit of love of life in all domains, self-love, love of others, loving good and love of life. In this paper I reflect on my own journey through growing up in Christchurch, and experiences around the world, that are the basis for that conclusion. In our efforts to pursuit bioethics education we can enhance peaceful and harmonius coexistence in our world, through nurturing good decisions that we should all make.
\end{abstract}

Key words: bioethics, peace, bioethics education, eubios,

Introduction: In the past three decades a systematic program of bioethics education has been implemented through Eubios Ethics Institute. This project aims to increase the love of life across the world.

The main products so far have been:

1) Production of cross cultural materials. Improvement via expert meetings. Adapted and translated in different languages to teach school and university classes about bioethics. Increasing the amount of free on-line teaching materials for bioethics education in different countries.

2) A network of teachers in different countries that have tried the materials, and created bioethics curricula for their local school, bioethics clubs and other endeavours.

3) A network of bioethics experts, in national and regional associations (including the Asian Bioethics
Association, All India Bioethics Association, Bangladesh Bioethics Society, and so on).

4) Development of Statements (e.g. Eubios Declaration of Bioethics, 2002; Joint action plan with UNESCO, 2006, and so on)

5) Testing of evaluation methods.

6) Sharing of museum displays and teacher training strategies.

7) Moral games and participatory methods

8) Teacher training workshops and government support.

9) Curriculum review and development.

10) Launch of dedicated Degree programs (e.g. Masters and PhD degree programs in Bioethics).

11) Strengthening Research-Policy Linkages

1. Pursuit of a Good Life (Eubios): In our pursuit of a good life (eubios), both individuals and societies, need to educate themselves on the pursuit of love of life in all 
domains, self-love, love of others, loving good and love of life. I coined the term eubios from Greek language as a response to the then commonly used terms "euthanasia" (good death) and "eugenics" (Good genes) because I think life ethics should be a more positive and holistic approach then what I had seen in much of the writings about these issues until then.

I have provided more of my background that led me to this conclusion in a paper published in the book, Legacies of Hope, Peace and Lovel where I reflect on my own journey through growing up in Christchurch, and experiences around the world, that are the basis for the conclusions expressed in the title of this paper. In our efforts to pursuit bioethics education we can enhance peaceful and harmonious coexistence in our world, through nurturing good decisions that we should all make.

\section{A Good Life (Eubios) Demands the} Culture of Peace: It seems like almost every day the news brings us pictures of violence, heartache, broken relationships, secular violence and so much more evidence that it is hatred which is the guiding principle of human interrelationships. Yet this was not what human beings were made to do according to the foundations of theories of human creation made in God's image. All human beings simply would like a good life (eu-bios), and the Universal Declaration of Human Rights declares it as an intrinsic right and obligation.

Legacies of hope is a project involving people of all ages, all religions, and many positive education and social systems, who argue that this much violence is enough. ${ }^{1}$ It is claimed that the Culture of Peace started in August 1945 when the Hiroshima and Nagasaki Atomic bombs showed that World Wars were no longer survival strategies ${ }^{2}$. How much further can we sit by and claim that this hatred is someone else's problem, when we still see the constant wars, terrorist attacks, and other acts of hate?

3. Commonalities of all Peoples: We are all born into the world, and we all die. We have a conscience and make moral decisions. Some of our ethics is linked to the group that we belong to, or claim to stem from. How do we define our affiliations? It's easy for a church or a mosque to disown a person who commits an act of hate or so-called hate crime and say then that the person is not one of us because they committed a criminal act to kill. This is one of the challenges that all religions face, how do deal with the violence that religion sometimes promotes. You may say it's not true that religion promotes hatred or the feeling of separation from those who are not the same faith. I would immediately reply it is one of my experiences inside many religious places of worship that the followers separate people into believers and the nonbelievers, and society in generally has the expression to talk about us and them. What makes a welcoming community, is when we do not feel that we are a moral stranger when we enter into a place together with others.

Over time people have been told that Jews, Brahmans, Christians and Muslims, and so on, are all the chosen race and chosen faith. Many indigenous people for millennia have been told that they are God's chosen people. 
People of many religions have been told to be exclusive, they may exclude options of marrying people from outside the faith, outside the village, or of going to a different country. These are ways that we exclude people from us. These other people become "them". These "them" are already distinguished as somehow foreign to us. In some countries such as the United States, foreign people are called "aliens". Fortunately, this is a word which Japan has dropped in the past decades for those who come from other places in the same planet. The racism and religious hatred are ways that people often use to avoid to associate with the "other".

So we can say that people should dispense with labels for others, beyond a personal name. This is why I implore others to simply call me Darryl. We need to expand the boundaries of who we consider to be moral agents in bioethics education, ${ }^{3}$ and there is a clear trend to do this over time. ${ }^{4}$ Environmental ethics education also includes peace education ${ }^{5}$.

This does not mean that we need to create some new label so that all are equal in the eyes of each other, such as man or woman. Distrust grows because we are often in a different place of worship, a place of peace and reflection. We should not call the people who are not members of the same faith, aliens. Even worse maybe "evil aliens" because the stranger killed somebody at some time in the past or present. So-called "primitive" societies had rituals of revenge where in the sad case of the death of somebody they would exchange life for a life, through a proportional method of execution so that the evil actions would be discouraged. But in the world of $21^{\text {st }}$ first century we are trying to build a commonality for people with a sustainable vision of universal human rights of love and legacy of inclusive education for everybody, and not be focused on the exclusion.

The legacies project is ongoing and open, so after reading the papers, poetry, and/or watching the videos please feel free to be inspired and contribute your own thinking to this project. The bioethics education projects continue, along with the focus provided by the Legacies project. Eubios Ethics Institute, means good-life Ethics Institute, and as a nongovernment organization formed in Christchurch, New Zealand we feel it is our duty and obligation to work for a better world than the one which we do not see ourselves to be in. Having had the privilege to grow up in an innocent and quiet, yet exciting town of Christchurch, it is a legacy for us to share this to those around as well as to try to replicate and share the experiences we have with other people.

\section{Bioethics Education and Cross Cultural} materials: In the past three decades a systematic program of bioethics education has been implemented through Eubios Ethics Institute. I wanted to make information on bioethics openly available to all, through the web, and low cost publications, because people in developing countries could not afford to purchase books or journals on this subject, and teachers did not have access to many materials.

This project aims to increase the love of life 
across the world. The rest of this paper will discuss the main products so far. The first was the production of cross cultural bioethics materials. These were improved via expert meetings and school trials. The materials were adapted and translated in different languages to teach school and university classes about bioethics ${ }^{3,6}$.

The balancing of principles that people use in moral decision making, such as self-love (autonomy), love of others (justice), loving life (do no harm) and loving good (beneficence) can provide us with a vehicle to express our values according to the desire to love life. ${ }^{4}$ Human beings are spiritual beings, sharing emotions such as love and hate, greed and generosity. Any system which fails to acknowledge this is destined to fail. We all may agree love is dominant in our mind, but how do we extend an emotion, to a system to analyze our decisions? Issues like justice, abortion, euthanasia, and stewardship of nature have been debated for millennia. We need to consider this diverse heritage when building a universal ethics. Differences in approaches are clear from early historical discussions of these issues, for example, there have always been people supporting and opposing euthanasia or abortion. There are debates in every country over questions such as whether to build roads or preserve biodiversity. These differences and similarities are seen within any group of people within every society. The social environment that people grow up in, and the education strategies, are being more similar with time suggesting that a universal approach is even more possible now than it was a century ago.
The more possibilities that we have, the more decisions that we need to make. Fortunately, standards of education are increasing, but this is no guarantee that the right decisions will be made even in democracies. People need to be taught more on how to make decisions, and the education system should accommodate this need of modern life, with a legal system that allows development of this capacity. The textbooks of bioethics were developed firstly in English and Japanese in the 1990s, and then expanded as more authors contributed materials. The support of the Ministry of Education, Culture and Welfare in Japan, and the Sasakawa Peace Foundation allowed trials of materials in many countries in the years $2001-2006^{3}$.

The materials continue to be available on-line for free download in editable form from Eubios Ethics Institute, and they were also made available on UNESCO website while I was serving as UNESCO Regional Adviser for Social and Human Sciences in Asia and the Pacific from 2004-2013.

\section{Bioethics Education Networks and} Bioethics Associations: At the same time that materials are being tested, networks of teachers in different countries who have tried the materials, and created bioethics curricula for their local school, bioethics clubs and other endeavours, were developed. The first bioethics education network that I developed was in Japan among teachers in 19967. The Eubios International Bioethics Education Network was initiated in 2004 and it is also linked to the International Association of Bioethics (IAB) International Bioethics 
Education network. These networks still exist, but many more persons around the world share experiences of bioethics education with each other at conferences, through publications, and the efforts are selfsustaining.

We could incorporate these goals of ethics education and (education) development of critical thinking through the inclusion of a global call for bioethics education by all states when they unanimously signed the 1997 Universal Declaration on the Human Genome and Human Rights, in article 20:

"20. States should take appropriate measures to promote the principles set out in the Declaration, through education and relevant means, inter alia through the conduct of research and training in interdisciplinary fields and through the promotion of education in bioethics, at all levels, in particular for those responsible for science policies" $"$.

Freedom of expression could be given more emphasis as a principle of bioethics. Article 19 of the 1948 Universal Declaration of Human Rights, upholds the "freedom to hold opinions without interference." Article 21 of Universal Declaration on the Human Genome and Human Rights 1997 "States should ... also undertake to facilitate on this subject an open international discussion, ensuring the free expression of various sociocultural, religious and philosophical opinions." In all societies there is a transition from Paternalism to informed consent to informed choice.

Network of bioethics experts have been supported through holding many roundtable workshops, in Tsukuba, Kumamoto, Bangkok and other places. These networks also led to the establishment of national and regional associations, including the Asian Bioethics Association, All India Bioethics Association, Bangladesh Bioethics Society, and so on.

\section{Development of Statements of Purpose} and the Goals of Bioethics Education: All sectors of society are faced with ethical issues in the pursuit of their duties. Critical to building the capacity of society for this open reflection on the goals of bioethics are educators. To ensure public participation and making wise decisions about their and their children's future, providing bioethics education at all levels is necessary. However how do we define the goals? The task of an educator includes empowering their students/learners to develop their maturity as individuals as well as being able to be cooperative members of changing societies. Learners, as we all should be, need to be prepared so they are able to apply knowledge to make good decisions during their life. How can we train educators and sustain their motivation to take upon this task? How can we create communities that are able to consider all sides of ethical debates?

Research has shown that there are a number of goals of bioethics education, as discussed in the Regional Action Plan for Bioethics Education that emerged from the UNESCO Asia-Pacific Conference on Bioethics Education (2006), including:

a) Knowledge: Development of transdisciplinary content knowledge. 
Understanding the advanced biological concepts. Being able to integrate the use of scientific knowledge, facts and ethical principles and argumentation in discussing cases involving moral dilemmas. Understanding the breadth of questions that are posed by advanced science and technology. Understanding of cultural values.

b) Skills: (capacity building in skill acquiring should be multi-faceted or many sided, and the goals include): Balancing benefits and risks of Science and Technology. Being able to undertake a risk/benefit analysis. Develop critical thinking and decision-making skills and reflective processes. Develop creative thinking skills. Develop foresight ability to evade possible risks of science and technology.

Skills for developing "informed choice"The required skills to detect bias in scientific method, interpretation and presentation of research results.

c) Personal moral development:

Understanding better the diversity of views of different persons. Increasing respect for all forms of life. Elicit a sense of moral obligation and values including honesty and responsibility. Being able to take different viewpoints to issues including both biocentric and ecocentric worldviews rather than only anthropocentric perspectives. Increasing respect for different people and culture, and their values. Developing scientific attitudes, reflective processes, and an ability for holistic appraisal, while not ignoring the value for reductionist analysis.

Knowledge about bias in the interpretation and presentation of research results, benefits and risks of technology and bioethical issues, and how to detect bias. Exploration of morals/values (values clarification). Values analysis and value based utilization of our scarce natural resources.

There are many other elements of the action plan, and it built on the Eubios Declaration of Bioethics (2002). To further mainstream bioethics, government adoption was necessary. So we could convene again with UNESCO. The UNESCO Regional Highlevel Meeting on the Teaching of Philosophy in Asia and the Pacific, held in Manila, Philippines, 25-26 May 2009, an action plan called "Thinking for the Future: An Action Plan for the Promotion of Philosophy Teaching in Asia and the Pacific" was agreed which set its first set of goals for philosophy education as the search for wisdom. The goals are broader than those for bioethics education, namely:

The outcomes of philosophy education include:

a) Understanding and a search for wisdom.

To this end we encourage:

Development of trans-disciplinary

knowledge

Clarification of concepts

Enhancement of the ability to integrate knowledge, principles and argumentation in rational discussion

Understanding the power of questions

Broadening intellectual horizons

Knowledge of cultural values in different communities

Search for meanings

Living a better life 
b) Development of capacities for:

Quality thinking and reflective processes

Wise judgment and decision-making

skills

Formulating appropriate questions

Creative thinking

Foresight

Reasoned choice

Interpretation, construction and

communication of knowledge

Respect for reasons and evidence

Better understanding of reality

c) Development of a disposition to:

Use knowledge and skills for good

Increasing respect for all forms of life

Take into account the interests of others

and the environment in the spirit of solidarity

Have empathy and compassion

Be tolerant, inclusive, and reasonable

Understand better the diversity of views

of different persons (listen to others)

Respect different points of view, people and culture, and their values

Reflect upon values

Consider alternative possibilities and world-views

Build and improve other virtues

The action plan also concluded on curriculum that: "Philosophy curricula based on research needs to be developed, adapted to local needs and integrated across all levels of education. Cooperation between different academic disciplines to encourage thinking and development of a transdisciplinary curriculum that achieves the above aims. Curriculum development workshops for in service and pre service teachers and for all levels of education needs to be organized." ${ }^{\prime}$

7) Testing of evaluation methods and pedagogical development: The task of a teacher includes empowering their students to develop their maturity as individuals as well as being able to be cooperative members of changing societies. Students need to be prepared so they are able to apply knowledge to make good decisions during their life. This begs the question of what is knowledge. How can we evaluate that students have learnt something useful?

Knowledge is much more than the latest trends in science and technology, or the latest political ideals. The wisdom from traditions of one's own, and many other communities are essential to the resources that our minds call "wisdom". How can we train teachers and sustain their motivation to take upon this vocation of sharing wisdom? How can we create communities that support these goals? There are various roles and challenges for teachers and educational institutions, and those who develop curriculum. Depending on the goals of the educational systems a variety of training strategies and methods will be used.

How can we empower teachers to make a special contribution in the wider context of constructing a mature society? Mature means a person, or a society that can balance the benefits and risks of alternative options, and make well-considered decisions, and talk about it. Evaluation of bioethics education was tested in many country trials in the Eubios Ethics Institute teaching trials ${ }^{9}$. 
The common social goal to respect the moral choices of others has developed hand in hand with the emergence of increased media attention in pluralistic democracies to display the divergent views on many topics. These dialogues can show us that local wisdom from our corner of the world is similar to local wisdom from others on the other side of the globe, so that they now also join to "us" to construct a larger "us". These lessons also assist us in the development of a globally accessible multicultural and multidisciplinary curriculum that offers cases from many local wisdoms that can be shared.

Some particular projects have also been supported such as sharing of museum displays and teacher training strategies. The background theory and many examples of games and methods to use in teaching are in Moral Games for Teaching Bioethics. This book describes the use of Moral games and participatory methods was published in association with the UNESCO Chair of Bioethics at Haifa. ${ }^{10}$ A persons' identity and ethic is developed based on their own and other people's opinions that grows as we face various dilemmas through our life. To have a balanced opinion from the community, it is important to hear from persons in a range of positions with different occupations. Interactive ethics education allows the classroom to be a place for moral exploration and clarification of values.

\section{8) Curriculum review and development:}

What can we teach in a curriculum that will influence the way that people make moral choices? Can a curriculum shape the future of our society to remove extremism, racism and hatred? Can we develop a global set of wisdom that covers many localities and includes local wisdoms? Consensus is possible after recognition of the individual yet connected history of relationships between different persons and communities, to try to preserve social harmony. This consensus building is seen even in countries that have structured paternalism affecting the relationships between persons.

We also assisted in the development of the UNESCO Bioethics Core Curriculum, which sets out to introduce the bioethical principles that countries of the world agreed to in the 2005 Universal Declaration on Bioethics and Human Rights. UNESCO developed a Bioethics Core Curriculum in 2009, based on the Universal Declaration on Bioethics and Human Rights (2005). In 2006 a second edition of teaching materials was developed by Eubios Ethics Institute in cooperation with UNESCO Bangkok, published for bioethics education trials in Asia-Pacific under the title, A Cross Cultural Introduction to Bioethics (CCIB). ${ }^{3}$ Each of those materials has learning objectives. In addition, in 2010 case studies were developed by my team in UNESCO Bangkok, linked specifically to the Bioethics Core Curriculum. In 2019 a SDG Curriculum, linked to the 17 Sustainable Development Goals (SDG) was also developed, a project which is also ongoing to provide open access resources for educators around the world on Eubios Ethics Institute website.

A review of the curriculum in 47 Asia-Pacific countries found that critical thinking is 
valued highly in all countries. ${ }^{11}$ Critical thinking capacity is essential for empowering persons to cope with changing times. How do we promote the creation of ideas, and individuality in an era of globalization? The rapid progress of technology has led to challenges in the way that we live. The systems and patterns that are seen in the relationships between patients, families, health professionals, and the society in general changed. Appropriate education requires teachers to apply methods and resources appropriately and to develop the decision-making ability in students, teachers and policy-makers so our society can evolve with the demands of the times.

There is also linkage to different goals of education through teaching guides. A teaching guide is available for CCIB to follow the organization of the Bioethics Core Curriculum and the case studies ${ }^{3}$. The teaching guide is structured that in each section it first introduces the CCIB chapter, than the case study. These teaching materials and teaching guide are all open to further additions, and feedback is welcomed. Eubios Ethics Institute provides many teaching materials that may be also used as teaching materials, and these are available also in Word format.

\section{9) Launch of dedicated Degree programs:}

Establishment of a new independent University, American University of Sovereign Nations (AUSN) in 2013 on Native American land in the United States, and of a new global Accreditation Commission, Accredited Universities of Sovereign Nations, in 2018. AUSN is organized as a 501(c)(3) non-profit entity, are providing opportunities to build up the capacity of trainers through offering Masters and Doctoral degree programmes. Recruitment of one hundred professors around the world to provide their time and skills to AUSN as allowed the emergence of a global bioethics' education program.

Establishment of the first Ph.D. program on federally recognized. Native American reservations in the United States (Doctorate in Bioethics, Sustainability and Global Public Health - offering specializations in Bioethics and Global Public Health, and Sustainability, Peace and Global Development) has led to wider provision of trained faculty. Establishment of seven Master Degree Programs also provides wide levels of training. Signing over 30 international collaborative agreements with Universities and other institutions around the world allows people to develop bioethics as a profession, and there is also an integrated Master of Science in Sustainability, Peace and Development from AUSN. The course on Global Public Health and Peace is mandatory in all Bioethics degree programs.

\section{0) Strengthening Research-Policy} Linkages and Conclusions: The creation of networks linking research into policy is a cornerstone of efforts in all levels, from local to regional. List serves function in English for educators and students, and persons from a wide range of countries have tried these resources, and contributed to this project over the past years.

We can see that there is a willingness to 
develop values education stimulated by recent reemergence of ethics education and philosophy education to equip all citizens to be better able to respond to the challenges of contemporary society. The precise way that we apply applied ethics to full transdisciplinary curricula across universities in higher learning for the good of society relies on local wisdom, but we can see that there are many common threads and all can benefit from this dialogue between civilizations and between persons to construct empowered individuals more capable of making moral judgments.

\section{References}

1. Macer DRJ. Ed., Legacies of Love, Peace and Hope: How Education can Overcome Hatred. Christchurch, N.Z.: Eubios Ethics Institute; 2019.

2. Fuchinoue $\mathrm{H}$. What has the A-bomb Dome Symbolized Over Time? in DRJ Macer (Ed.). Asian-Arab Philosophical Dialogues on Culture of Peace and Human Dignity. Bangkok: UNESCO; 2011. 56-71.

3. Macer DRJ. Cross Cultural Introduction to Bioethics. Christchurch, N.Z.: Eubios Ethics Institute; 2006. Available from https://www.eubios.info/publications_links

4. Macer DRJ. Bioethics is Love of Life. Christchurch, N.Z.: Eubios Ethics Institute; 1998. Available from https://www.eubios.info/publications_links

5. Baker M, Grundy M, Junmookda K, Macer DRJ, Manzanero LI, Reyes D, Ngo TT, Waller A. Environmental Ethics Education. Christchurch, N.Z.: Eubios Ethics Institute; 2019.

Author Contributions: The Author conceived the idea, wrote the manuscript and checked the manuscript meticulously.

Conflict of interests: No conflict of interest in this study to declare.
6. Macer, DRJ. Bioethics education for informed citizens across cultures. School Science Review 86 (December 2004), 83-86.

7. Asada Y, Akiyama S, Tsuzuki M, Macer NY, Macer DRJ High school teaching of bioethics in New Zealand, Australia, and Japan. Journal of Moral Education, 1996; 25: 401-420.

8. UNESCO. Universal Declaration on the Human Genome and Human Rights. Paris: UNESCO, 1997.

9. Macer DRJ. (Ed.). Asia-Pacific Perspectives on Bioethics Education. Bangkok: UNESCO; 2008.

10. Macer DRJ. Moral Games for Teaching Bioethics Haifa: UNESCO Chair for Bioethics; 2008. Available from https://www.eubios.info/publications_links

11. Wolf A, Macer, DRJ._Conceptual Maps of the Goals of Teaching Philosophy and Human Dignity in DRJ Macer (Ed.). Asian-Arab Philosophical Dialogues on Culture of Peace and Human Dignity. Bangkok: UNESCO; 2011, 104-110.

Further Information:

While it is desirable to find culturally appropriate terms to refer to philosophy, such as thinking for the future, at each level of education these goals apply to broader goals of education and development of thinking in general.

Further information on specific training programs for Postgraduate Certificates, Masters, and Doctoral degrees in these subjects are offered through American University of Sovereign Nations and may be found at https://www.ausovereignnations.org

Education listserve

$<$ http://groups.yahoo.com/group/Bioethicseducation/ $>$

Student listserve http:/groups.yahoo.com/group/ Bioethics for_students/ 